Изучение теории государства и права имеет важное значение для формирования высокой правовой культуры государственных служащих, административных работников и специалистов всех отраслей хозяйства, преодоления в их профессиональном сознании правового нигилизма и правового фетишизма. Усвоение теоретических правовых знаний развивает самостоятельное и творческое мышление в решении научных и практических задач государственно-правового строительства, обеспечения формирования устойчивой рыночной экономики, общественной безопасности, защиты законных прав и интересов граждан юридическими средствами и методами.

\section{Список цитированных источников}

1. Широков, А. Т. Теория государства и права: курс лекций / А. Т. Широков. - Минск : Акад. упр. при Президенте Респ. Беларусь, 2009. - 154 с.

2. Вышинский, А. Я. Вопросы теории государства и права / А. Я. Вышинский. - М. : Госюриздат, 1949. - 419 с.

3. Рассказов, Л. П. Теория государства и права: углубленный курс: учеб. / Л. П. Рассказов. - М. : РИОР: ИНФРА-М, 2015. - 559 с.

4. Нерсесянц, В. С. Общая теория права и государства : учеб. / В. С. Нерсесянц. - М. : Норма : ИНФРА-М, 2012. - 560 с.
5. Зорченко, Е. А. Теория государства и права : пособие / Е. А. Зорченко, Н. А. Полящук, Н. М. Юрашевич; под общ. ред. Н.М. Юрашевич. - 2-е изд., испр. и доп. - Минск : Акад. упр. при Президенте Респ. Беларусь, 2013. - 363 с.

6. Сенин, И. Н. Культура преподавания дисциплины «Теория государства и права» / И. Н. Сенин // Инновационное образование и экономика. 2011. - № 9. - С. 41-43.

7. Кузьмин, И. А. Особенности и перспективы преподавания дисциплины «Теория государства и права» в Академии Генеральной прокуратуры Российской Федерации / И. А. Кузьмин // Особенности преподавания юридических дисциплин в Академии Генеральной прокуратуры Российской Федерации : материалы межкаф. кругл. стола / под общ. ред. А. П. Горелика. - М.: Академия Генеральной прокуратуры Российской Федерации, 2017. - С. 33-41.

8. Вербицкий, А. А. Контекстное обучение: понятие и содержание / А. А. Вербицкий // Эксперимент и инновации в школе. - 2009. - № 4. C. $8-13$.

9. Общая теория права: пособие / В. А. Абрамович [и др.]; под общ. ред. С. Г. Дробязко, С. А. Калинина. - Минск: БГУ, Четыре четверти, 2014. $-416 \mathrm{c}$.

\title{
ПЕРСПЕКТИВЫ ВНЕДРЕНИЯ АДАПТИВНОЙ ФИЗИЧЕСКОЙ КУЛЬТУРЫ И СПОРТА В ВУЗЕ
}

Федоров В. $\boldsymbol{A}$.

Студент 1 курса БГТУ,

2. Брянск РФ

Карева $\boldsymbol{\Gamma . ~ В . ~}$

доиент,к.п.н.«ФВи С»БГТУ,

2. Брянск $Р \Phi$

Аннотация. В данной статье рассматриваются перспективы внедрения адаптивной физической культуры и спорта в вузе.

Ключевые слова: Физическая культура, студенты, адаптивная физическая культура; люди с ограниченными возможностями.

Каждый год около 14\% студентов, поступаюших в вузы России, оказываются в специальной медицинской группе, на основании полученных диагнозов. Возрастание инвалидности среди обучающихся обуславливается неблагоприятной экологической обстановкой, усложнением производственных процессов.

Физкультура играет важную роль во взрослении и становлении человека как индивида. Этот способ воспитания учит движениям, выносливости, дает возможность овладеть физкультурными знаниями. Физкультура и спорт в принципе очень важны как для всех студентов вузов России, так и для студентов с ограниченными физическими возможностями здоровья.

Адаптивная физическая культура (АФК) - это совокупность мер спортивно-оздоровительного комплекса, направленных на востановление и адаптацию к обычной социальной среде людей с ограниченными возможностями, преодоление психологических трудностей, тормозивших осознанию полной жизни. Регулярные занятия АФК значимо расширяют разнообразие функциональных способностей студентов с ограничениями, улучшают состояние опорно-двигательной системы, воздействуют на психику. Адаптация таких студентов к физическим нагрузкам является актуальной проблемой всех вузов страны, нуждающаяся в решении на протяжении многих лет обучения.

Адаптивная физическая культура для студентов с ограниченными возможностями здоровья создает:

- осознание личных физических возможностей;

- способность бороть физические и психологические преграды, мешающие ведению полной жизни; 
- постановку цели у студентов-инвалидов к стремлению вести здоровый образ жизни;

- желание делать лучше свои навыки и физические способности;

- способность адаптироваться в обществе.

Целью АФК является не только улучшение навыков физической подготовки, но и социализация студента с ограниченными физическими возможностями здоровья, улучшение качества жизни человека, заполнение жизни новыми эмоциями, знакомствами, общением. [1]

Организация занятий и всего учебного процесса адаптивной физкультуры для студентов-инвалидов сильно отличается от обычной программы занятий физкультурой в вузах и имеет свои аспекты. В программу для студентов специальной медицинской группы входит: изучение теории, практического материала, адаптивная физическая активность.

Занятия адаптированной физкультурой обычно начинаться с предварительного периода. Его длительность часто зависит от здоровья студента. Далее следует основной период: $30 \%$ расходуется на лечебную физическую культуру (ЛФК) и 60\% на спец подготовку и $10 \%$ на занятия ЛФК с полноценным медицинским обследованием. Программа адаптивной физкультуры уменьшает количество упражнений на развитие силы и выносливости. Завершает цикл переходный период. Его основная задача - постепенное уменьшение нагрузок, развитие технических приёмов.

Для обучения адаптивной физической культуре студентов с ограниченными физическими возможностями существуют различные параметры, зависящие от состояния здоровья студента. Например, для обучения студентов с ограничением по зрению поверхность покрытия в спорт зале обязана быть ровной и гладкой; надо предусматривать звукопоглощающие потолки и стены, а еще обеспечение акустической изоляции. Эффективность физических занятий обусловлена структурой движений, последовательностью, продолжительностью занятий, частным подходом к выбору физических занятий. При ДЦП уделяют внимание не только развитию мышц, суставов, координации движения, но и зрению, речи и другим проблемам со здоровьем. Профилактическая цель является в проведении мер, нацеленных на общее улучшение самочувствия человека, повышение сил и возможностей, укрепление иммунитета. [2]

В данный момент многие вузы России осуществляют проведение курса адаптивной физической культуры. Однако развитие данной дисциплины и внедрение ее в образовательные программы высших учебных заведений породили большое количество трудностей и противоречий, обусловленных слабым уровнем разработки этой программы.

Можно выделить некоторые причины
недостаточной развитости программы адаптированной физической культуры для студентов с ограниченными физическими возможностями здоровья:

Плохие социально-экономические условия для выполнения данной задачи;

Малое понимание важности адаптивной физической культуры среди государственных деятелей Российской Федерации;

Улучшение физкультуры и спорта для студентов с ограниченными возможностями не является значимой задачей страны;

Отсутствие возможности для привлечения студентов-инвалидов к занятию спорта;

Малый профессионализм тех, кто занимается обучением адаптивной физической культуре, отсутствие у преподователей медицинского образования;

Малое желания занятия спортом у самих студентов с ограниченными возможностями здоровья.

Bсе эти факторы препятствуют достижению высокого уровня развитости адаптивной физической культуры среди высших учебных заведений России. Решение данных проблем является очень важной задачей, так как физическая активность необходима не только основному проценту здоровых студентов, но и студентам с ограниченными возможностями здоровья. [3]

Повышение эффективности занятий адаптивной физической культурой позволит поднять на новый качественный уровень социальной практики физическую культуру, образование, всю систему именно комплексной реабилитации студентов с проблемами со здоровьем, наладит уровень жизни и коммуникаций в обществе. Наличие у студентов различных диагнозов требует постоянного осведомления и внимательной и кропотливой работы от преподавателя, который должен периодически изучать новые и подходящие варианты обучения, проведения аттестаций, пересматривать нормативы и задания.

\section{Список литературы:}

1. Основы адаптивной физической культуры: Учебн. пособие. - М. Физкультура и спорт, 2007. 192 c.;

2. Аксенова О.Э., Евсеев С.П. Технологии физкультурно-спортивной деятельности в адаптивной физической культуре//Учебное пособие. -М.: Советский спорт, 2004. -296 с.

3. Курдыбайло С.Ф., Евсеев, С.П., Герасимова Г.В. Врачебный контроль в адаптивной физической культуре//Учебное пособие. -М.: Советский спорт, 2004. -184 c.

(C) Федоров В.А., 2019 